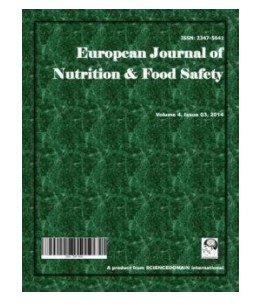

\title{
Phytochemical Composition and Antioxidant Activity of Fermented Moringa oleifera Leaf Powder
}

\author{
Harimalala Andriambelo Nirina ${ }^{1^{*}}$, Rasoarinanahary Miora ${ }^{1}$, Porphyre Vincent ${ }^{2,3}$, \\ Hiol Abel $^{2,3}$, Remize Fabienne ${ }^{2,3}$ and Razanamparany Louisette ${ }^{1}$ \\ ${ }^{1}$ Science and Technology, Food Science and Nutrition, Laboratory of Applied Biochemistry in Food \\ Science and Nutrition, University of Antananarivo, Madagascar. \\ ${ }^{2}$ Higher School of Engineers Reunion Indian Ocean, University Technology Park, 2 Rue Joseph \\ Wetzell, 97490 Saint-Denis, France. \\ ${ }^{3}$ CIRAD, UMR QUALISUD, Joint Research Unit, University of La Réunion, PTU 97490, France.
}

\section{Authors' contributions}

This work was carried out in collaboration between all authors. Author RL headed the project. Authors HAN and RM conducted the analysis and interpretation. Author HAN drafted the manuscript. Authors RF and HA were involved in the early work and assisted with the interpretation of the results.

Author PV found the project financing. Both authors were involved in the critical revision of the manuscript for important intellectual content. All authors read and approved the final manuscript.

Article Information

DOI: $10.9734 / E J N F S / 2017 / 29627$

Original Research Article

Received $21^{\text {st }}$ September 2016

Accepted $5^{\text {th }}$ July 2017

Published 11 ${ }^{\text {th }}$ July 2017

\section{ABSTRACT}

The aim of this study was to determine the effects of lactic fermentation of Moringa oleifera leaf powder at young and mature stage of development. This is to improve the organoleptic quality of Moringa oleifera leaf powder. The work was performed in the laboratory of high School of Engineering of La Reunion. The fermentation was performed by Lactobacillus plantarum (DSM 2601 ) and Weissella cibaria (27A) inoculated at $10^{6} \mathrm{CFU} / \mathrm{g}$. The fermentation was performed at $25^{\circ} \mathrm{C}$ over 5 days. An acidification of fermented products $(4<$ final $\mathrm{pH}<5)$, a high protein content in mature leaves fermented over 120 hours (T120-Ma), or over $48 \mathrm{~h}$ (T48-Ma), by Weissella cibaria, a high protein content in mature leaves fermented over $120 \mathrm{~h}$ (T120-Ma) and in young leaves fermented over $120 \mathrm{~h}$ (T120-I) by Lactobacillus plantarum was observed. The results of ANOVA on fermentation by Weissella cibaria (27A) and Lactobacillus plantarum (DMS 2601) on the nutritional leaves of Moringa oleifera, showed there was no significant effect on the $\alpha=0,05$ fermentation times and stage of leaves maturity for contents of reducing sugar and proteins. But there is a significant effect of fermentation and maturation stage leaves on the $\mathrm{pH}$ of the product threshold at $\alpha=0.05$. The fermentation by Lactobacillus plantarum (DMS 2601) showed there was an effect of the fermentation time on the content of phenolic compounds. Principal component 
analysis (PCA) showed that there is a negative correlation between the protein content and the content of phenolic compounds. By the fermentation process, the organoleptic characteristics of the Moringa oleifera leaves powders whose color is to be improved, which is an asset in the process of incorporation of Moringa oleifera. Lactic fermentation of Moringa oleifera leaves is a method of increasing protein intake of the food and the fight against PEM target populations.

Keywords: Moringa oleifera; fermentation; Lactobacillus plantarum; Weissella cibaria; chemical composition; antioxidant activity.

\section{INTRODUCTION}

Protein malnutrition affects populations in most of the southern countries, like Madagascar. In this country, in 2012-2013, the proportion of the population living below the national poverty line was $71.5 \%$ and in the extreme poverty was $52.7 \%$. This poverty results in a diet consisting of low-cost roots and tubers with intakes of $477 \mathrm{~g} /$ day / person [1]. Malnutrition is caused by low household income, and by ignorance and lack of exploitation of edible and available natural resources. Moringa oleifera is a plant that grows in the wild or that serves hedge for homes in coastal areas and it is relegated to the back by the highlands population. But in the South, $M$. oleifera leaves are a new food resource, an important source of protein, vitamins and minerals which helps to fight against malnutrition $[2,3,4,5]$. M. oleifera is also used in traditional medicine and is known to be rich in antioxidants, especially polyphenols and flavonoids which can prevent degenerative diseases. Among other to use to struggle against malnutrition, $M$. oleifera serves for enriching different food in proteins and minerals $[3,6,5]$. It serves as a nutritional supplement for example in biscuits and in traditional dishes $[7,8,9]$.

Technological processes are searched to improve the bioavailability of nutrients and to increase the energy density of food [10]. It's possible to name the case of lactic fermentation improves the organoleptic properties of food and health and conservation [11,12]. The organisms implicated are the lactic bacteria such as Lactobacillus plantarum. It is used for example in the fermentation of corn pastes, sauerkraut lemon and others foods based on wheat $[13,14,15]$.

All over beneficial effect nutritional and health benefits of $M$. oleifera leaves, and in order to increase protein intake, we determined the effect of fermentation on powders leaves by $L b$. plantarum and Weissella cibaria on nutritional composition, on antioxidant capacity as well as on the organoleptic properties especially the food color. Indeed, color as well as texture are important factors to determine sensory quality and acceptability of the consumers for food products. These parameters are needed to improve the process of incorporating the powders of $M$. oleifera leaves in food [3].

\section{MATERIALS AND METHODS}

\subsection{Plant Material}

The leaves of $M$. oleifera were collected at Tamatave, east coast of Madagascar, in March and April 2015. The leaves were collected and separated in three groups: the first group constituted by young leaves (yo), the second group made of mature leaves (Ma) and the third group was leaves without stage distinction (lea). In this work, the difference between the young and the mature leaves was tenderness and color. The young leaves were tenderer, light green color compared to older leaves which were harder and dark green. Leaves were washed and then dried in ventilated room during 3 days and were regularly stirred: twice a day to avoid mold growing. The dried leaves were powdered with a mixer and stored in dark bag and in a dry place.

\subsection{Microorganisms}

The strains used in this study were $L b$. plantarum DSM 2601 and $W$. cibaria 27A provided from the Microbiology Laboratory of QualiSud, Université of La Réunion.

\subsection{Culture of Bacteria}

Lb. plantarum DSM 2601 and W. cibaria 27A were propagated in de Man, Rogosa and Sharpe (MRS) broth $\left(\mathrm{pH} \mathrm{5,5)}\right.$ at $37^{\circ} \mathrm{C}$ for $72 \mathrm{~h}$ for activation. The cell number was approximately $10^{8} \mathrm{UFC} / \mathrm{ml}$. The cultures obtained were used for the inoculation of powdered $M$. oleifera leaves solution. 


\subsection{Preparation of $M$. oleifera Powder Solution}

A mass of $50 \mathrm{~g}$ of leaf powder, young (Yo), mature (Ma) or leaves without distinction of maturity (Lea), were introduced into an Erlenmeyer flask of $1000 \mathrm{ml}$ and $400 \mathrm{ml}$ of distilled water was added. It was sterilized at $120^{\circ} \mathrm{C}$ for $20 \mathrm{~min}$. After cooling, the preparation of powders leaves were inoculated with $L b$. plantarum (DSM 2601) and W. cibaria (27A) at $10^{6} \mathrm{UFC} / \mathrm{ml}$.

The mixtures were homogenized at $150 \mathrm{rpm}$ and the fermentation was carried out at $25^{\circ} \mathrm{C}$ for 120 hours (5 days). Sample without bacteria was made as control.

\subsection{Chemicals Analysis}

The moisture content was determined on the powder of $M$. oleifera leaves: young (Yo), mature (Ma) and leaves without distinction of maturity (Lea).

Over incubation, $50 \mathrm{ml}$ of each sample were removed immediately after inoculation (T0), after 48h (T48) and after $120 \mathrm{~h}$ (T120). Counts of DSM 2601 and 27A were estimated by optical density measurement at $660 \mathrm{~nm}$. The $\mathrm{pH}$ value was measured with a $\mathrm{pH}$ meter.

Then, the samples were centrifuged at $10^{\circ} \mathrm{C}, 15$ $\min , 5000 \times g$ and the supernatants were used for the analysis:

$\checkmark$ Reducing sugars, resulting product of hydrolysis, were determined by the dinitrosalicylic acid (DNS) method of Miller (1959) with some modifications: $500 \mu \mathrm{l}$ of diluted supernatant (1/6 or $1 / 8)$ was mixed with $750 \mu \mathrm{l}$ DNS reagent. The reaction mixture was plugged with aluminum paper and boiled in a water bath $100^{\circ} \mathrm{C}$ for $5 \mathrm{~min}$ and cooled to room temperature in a water ice bath. Then, $7.5 \mathrm{ml}$ of distilled water was added. The absorbance was measured at $540 \mathrm{~nm}$ using a spectrophotometer. A calibration curve was prepared using a standard solution of glucose $1 \mathrm{~g} / \mathrm{l}$;

$\checkmark$ Total protein content was determined by the method of Bradford (1976): $100 \mu \mathrm{l}$ of diluted extract $(1 / 2)$ was mixed with $3 \mathrm{ml}$ of the Coomassie reagent, incubated at room temperature for $15 \mathrm{~min}$ and the absorbance was measured at $594 \mathrm{~nm}$. A standard solution was prepared using bovine serum albumin (BSA) $1 \mathrm{~g} / \mathrm{l}$;

$\checkmark$ The total phenolic compound content was estimated by the method of Singleton and Rossini (1965) using Folin-Ciocalteu regent: $30 \mu \mathrm{l}$ of the acetone extract and of the aqueous extract in distilled water $(1 / 8$ and $1 / 150$ ) was mixed with $15 \mu$ l of Folin Ciocalteu reagent. After $5 \mathrm{~min}$ at room temperature, $60 \mu \mathrm{l}$ of $\mathrm{Na}_{2} \mathrm{CO}_{3} 2 \%$ were added. Then, $195 \mu$ l distilled water were added and incubated for $1 \mathrm{~h}$ in the dark, the absorbance was read at $760 \mathrm{~nm}$ with a spectrophotometer against blank. The blank was made from distilled water with all the reactives. The total phenolic compound was calculated using a standard solution of $1 \mathrm{mg} / \mathrm{ml}$ acid Gallic, the results were expressed as $\mathrm{mg}$ acid Gallic equivalents / $100 \mathrm{~g}$ of extract.

$\checkmark$ The color of M. oleifera leaf powder was assessed using a Chroma meter, using the color space $\left(L^{*} a{ }^{*} b\right)$. The instrument was calibrated with standard white reflector plate of the device.

Each extraction assays were done in triplicate.

\subsection{Statistical Analysis}

To characterize the nutritional properties of fermented powder leaves, an analysis of variance (ANOVA) using 2 factors (fermentation and maturity of leaves) multiple comparison test with the Fischer test at $95 \%$ confidence level was performed. An Analysis with principal components (ACP) was carried out to highlight the differences between products. Statistical analyzes were carried out using the software XLTSAT 7.0 to identify the difference between the products.

\section{RESULTS AND DISCUSSION}

\subsection{Effects of Fermentation on Nutritional Properties of $M$. oleifera Leaves}

To study the evolution of leaf powder at the various stages of maturation (young, mature and mixtures) over lactic fermentation (T0, T48, T120), optical density measurements (OD), $\mathrm{pH}$, reducing sugars (RS), proteins (PR), and Phenolic compounds (PC) level determination were performed. Data are presented in Tables 1 and 2. 
Table 1. Effects of fermentation by $W$. cibaria (27A) on the nutritional leaves of $M$. oleifera

\begin{tabular}{|c|c|c|c|c|c|c|}
\hline $27 A$ & $\begin{array}{l}\text { Fermentation } \\
\text { time }\end{array}$ & OD $^{1}$ & $\mathrm{pH}$ & $\mathbf{R S}^{2}$ & $\mathbf{P C}^{3}$ & $\mathbf{P R}^{4}$ \\
\hline \multirow[t]{3}{*}{ Young (Yo) } & T0 & $2.4^{A}$ & $5.2^{A B}$ & $21.5 \pm 0.1^{A}$ & $21.5 \pm 0.1^{\mathrm{AB}}$ & $3.4 \pm 0.3^{A}$ \\
\hline & $\mathrm{T} 48$ & $1.8^{A B}$ & $4.7^{\mathrm{A}}$ & $17.8 \pm 0.1^{\mathrm{A}}$ & $21.6 \pm 0.1^{\mathrm{AB}}$ & $4.6 \pm 0.1^{\mathrm{A}}$ \\
\hline & T120 & $1.9^{A B}$ & $4.7^{\mathrm{A}}$ & $23.4 \pm 0.1^{\mathrm{A}}$ & $10.9 \pm 0.1^{\text {АВА }}$ & $10.1 \pm 0.1^{\mathrm{AB}}$ \\
\hline \multirow[t]{3}{*}{ Matures (Ma) } & TO & $1.9^{\mathrm{A}}$ & $5.2^{\mathrm{B}}$ & $5.4 \pm 0.1^{\mathrm{A}}$ & $28.3 \pm 0.1^{\mathrm{B}}$ & $4.7 \pm 0.1^{\mathrm{A}}$ \\
\hline & T48 & $2.2^{A B}$ & $4.9^{\mathrm{AB}}$ & $15.2 \pm 0.2^{\mathrm{A}}$ & $15.1 \pm 0.1^{b}$ & $7.2 \pm 0.1^{\mathrm{A}}$ \\
\hline & T120 & $2.5^{\mathrm{AB}}$ & $4.7^{\mathrm{AB}}$ & $22.8 \pm 0.1^{\mathrm{A}}$ & $7.2 \pm 0.1^{\mathrm{A}}$ & $7.5 \pm 0.1^{\mathrm{AB}}$ \\
\hline \multirow{3}{*}{$\begin{array}{l}\text { Leaves without } \\
\text { distinction (Lea) }\end{array}$} & TO & $1.5^{\mathrm{A}}$ & $5.2^{B}$ & $4.1 \pm 0.1^{\mathrm{A}}$ & $20.4 \pm 0.1^{\mathrm{AB}}$ & $6.9 \pm 0.1^{\mathrm{A}}$ \\
\hline & $\mathrm{T} 48$ & $2.8^{\mathrm{AB}}$ & $5.2^{\mathrm{AB}}$ & $11.0 \pm 0.1^{\mathrm{A}}$ & $15.2 \pm 0.1^{\mathrm{AB}}$ & $6.9 \pm 0.1^{\mathrm{A}}$ \\
\hline & T120 & $2.5^{\mathrm{AB}}$ & $5.2^{\mathrm{AB}}$ & $14.9 \pm 0.1^{\mathrm{A}}$ & $4.8 \pm 0.1^{\mathrm{A}}$ & $7.7 \pm 0.1^{\mathrm{AB}}$ \\
\hline
\end{tabular}

Table 2. Effects of fermentation by Lb. plantarum (DSM 2601) on the nutritional leaves of M. oleifera

\begin{tabular}{lllllll}
\hline DSM & Age & OD $^{1}$ & PH & RS $^{2}$ & PC $^{3}$ & PR $^{\mathbf{4}}$ \\
\hline Young & T0 & $0.7^{\mathrm{A}}$ & $5.1^{\mathrm{AB}}$ & $18.1 \pm 0.2^{\mathrm{BA}}$ & $18.2 \pm 0.1^{\mathrm{AC}}$ & $3.4 \pm 0.1^{\mathrm{A}}$ \\
(Yo) & T48 & $2.7^{\mathrm{A}}$ & $4.3^{\mathrm{A}}$ & $19.3 \pm 0.1^{\mathrm{BA}}$ & $24.0 \pm 0.1^{\mathrm{AB}}$ & $4.5 \pm 0.1^{\mathrm{AB}}$ \\
& T120 & $2.0^{\mathrm{A}}$ & $4.6^{\mathrm{A}}$ & $13.9 \pm 0.1^{\mathrm{AB}}$ & $6.1 \pm 0.1^{\mathrm{A}}$ & $7.4 \pm 0.1^{\mathrm{AB}}$ \\
Matures & T0 & $0.9^{\mathrm{A}}$ & $5.3^{\mathrm{AB}}$ & $16.0 \pm 0.1^{\mathrm{A}}$ & $30.1 \pm 0.1^{\mathrm{AC}}$ & $3.3 \pm 0.3^{\mathrm{A}}$ \\
(Ma) & T48 & $2.1^{\mathrm{A}}$ & $4.8^{\mathrm{AB}}$ & $20.2 \pm 0.1^{\mathrm{A}}$ & $21.5 \pm 0.1^{\mathrm{B}}$ & $5.0 \pm 0.1^{\mathrm{AB}}$ \\
& $\mathrm{T} 120$ & $2.5^{\mathrm{A}}$ & $4.9^{\mathrm{AB}}$ & $20.5 \pm 0.1^{\mathrm{A}}$ & $10.4 \pm 0.1^{\mathrm{A}}$ & $9.9 \pm 0.1^{\mathrm{AB}}$ \\
Leaves without & T0 & $0.9^{\mathrm{A}}$ & $5.3^{\mathrm{B}}$ & $9.1 \pm 0.1^{\mathrm{A}}$ & $19.0 \pm 0.1^{\mathrm{AC}}$ & $2.9 \pm 0.1^{\mathrm{A}}$ \\
distinction & T48 & $2.7^{\mathrm{A}}$ & $5.1^{\mathrm{BA}}$ & $22.3 \pm 0.1^{\mathrm{A}}$ & $7.4 \pm 0.1^{\mathrm{AB}}$ & $4.4 \pm 0.1^{\mathrm{AB}}$ \\
(Lea) & T120 & $2.7^{\mathrm{A}}$ & $5.1^{\mathrm{BA}}$ & $22.3 \pm 0.1^{\mathrm{A}}$ & $7.4 \pm 0.1^{\mathrm{A}}$ & $4.4 \pm 0.1^{\mathrm{AB}}$ \\
\hline
\end{tabular}

The results of ANOVA showed that there was no significant effect on the threshold $\alpha=0.05$ fermentation time and stage of plant maturity on the levels of reducing sugars $(p=0.334 ; p=$ $0.893)$, phenolic compounds $(p=0.077 ; p=$ $0.235)$ and protein $(p=0.062 ; p=0.299)$.

Statistical analysis showed no significant effect at $\alpha=0.05$ fermentation time and stage of leaves maturity for contents of reducing sugars $(p=$ $0.090 ; p=0.114)$ and proteins $(p=0.062 ; p=$ 0.299). But, in the mature stage, the fermentation time influences the content of phenolic compounds $(p=0.014)$.

So generally, statistical analysis showed that there was no significant effect of fermentation and maturation stage leaves on nutritional parameters of the product, but there is a significant effect of fermentation and maturation stage leaves on the $\mathrm{pH}$ of the product threshold at $\alpha=0.05$. To find the difference that may exist between the fermented products, it is made an analysis in principal components where the variables are projected (Fig. 1a and 1b).

The analysis in ACP STATE, characterize the products T120-Ma, T120-Me, T48-Me and T120yo strongly correlated which are rich in protein (Fig. 1a). In Fig. 1b, the products T120-Ma and
T48-Ma are correlated with the variables proteins and sugars reducers. These products are opposed to T0-Me if considers the variable compounds phenolic.

\subsection{Effects of Fermentation on the Chromacity of $M$. oleifera Leaves}

The values $(L, a, b)$ of fermentation effect are indicated in the Table $3 \mathrm{a}$ and $3 \mathrm{~b}$. The values of ( $\mathrm{L}, \mathrm{a}, \mathrm{b})$ put on the chromacity diagram shows the color of the fermented powder is situated in the area (white, green, yellow).

Table 3a. Colorimetric measurement of young powder leaves fermented by $L b$. plantarum (DSM2601)

\begin{tabular}{lll}
\hline Time (T) & $\mathbf{0}$ & $\mathbf{4 8}$ \\
\hline $\mathrm{L}$ & 59.0 & 58.8 \\
$\mathrm{a}$ & -8.0 & -2.9 \\
$\mathrm{~b}$ & 34.0 & 33.5 \\
\hline
\end{tabular}

Table 3b. Colorimetric measurement of young powder leaves fermented by $W$. cibaria (27A)

\begin{tabular}{lll}
\hline Time (T) & $\mathbf{0}$ & $\mathbf{4 8}$ \\
\hline $\mathrm{L}$ & 59.9 & 59.5 \\
$\mathrm{a}$ & -7.1 & -1.7 \\
$\mathrm{~b}$ & 35.6 & 35.1 \\
\hline
\end{tabular}




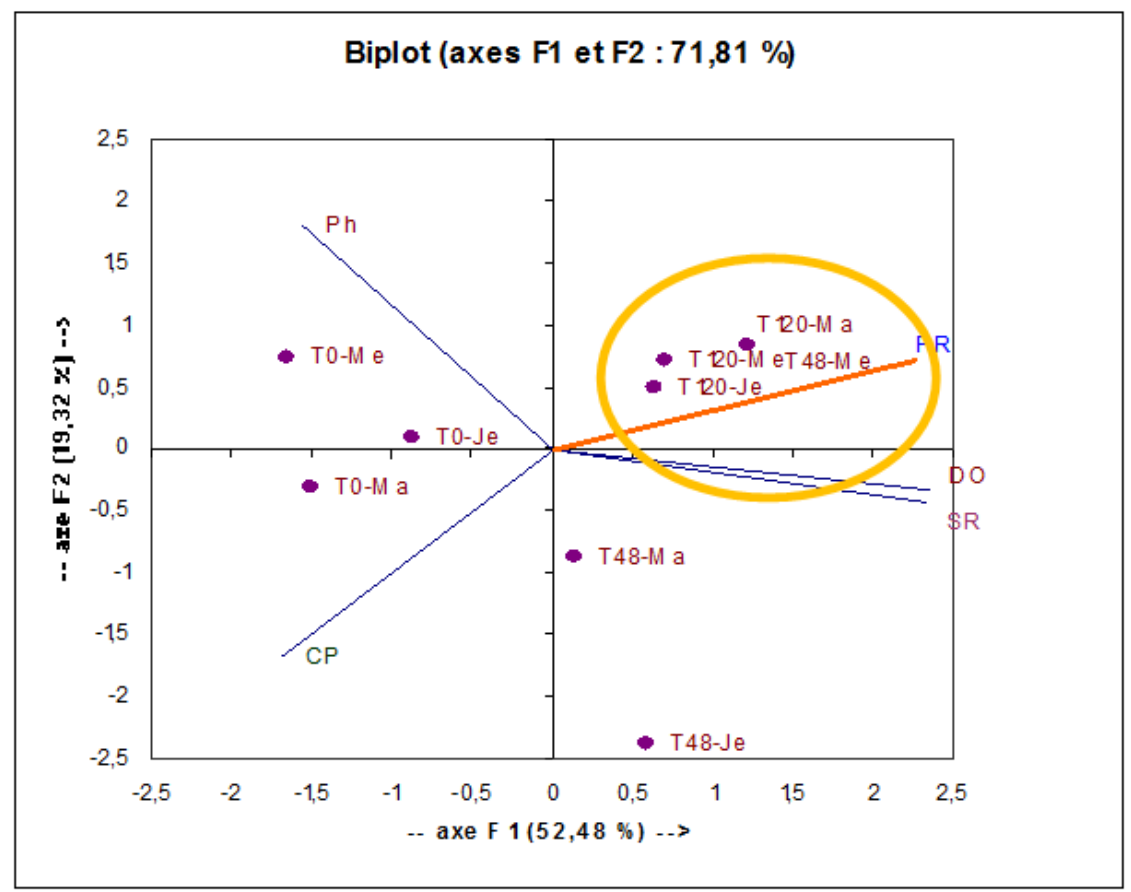

Fig. 1a. Principal components analysis of fermented leaves by Lb. plantarum (DSM 2601) according to the time of fermentation and maturity of the plant

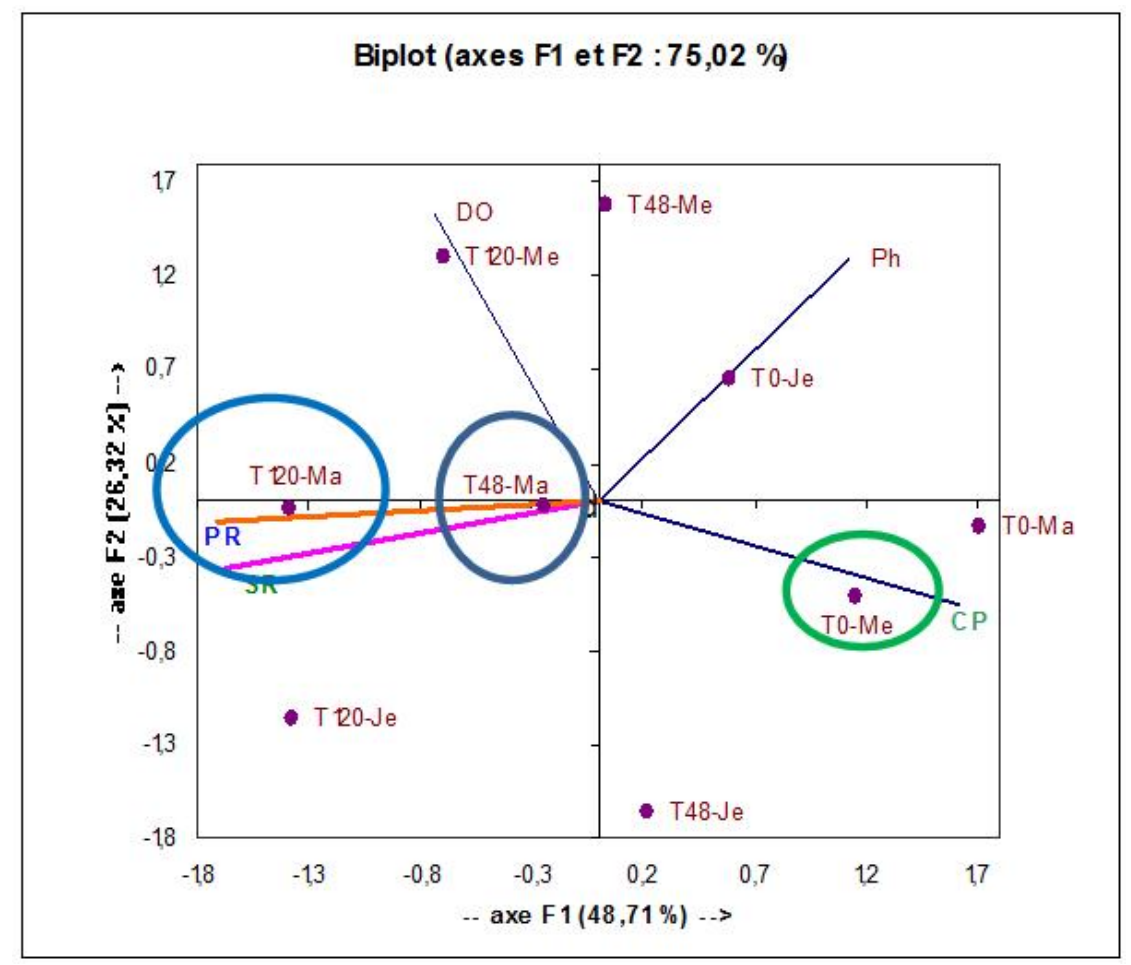

Fig. 1b. Principal components analysis of fermented leaves by $W$. cibaria (27A) according to the time of fermentation and maturity of the plant 
There is thus obtained a clarified product. This parameter could be exploited to improve its visual aspect. Indeed, a visual comparison of the powder $M$. oleifera leaves fermented and not fermented shows a difference of coloring in the green (Fig. 2a and 2b).

The fermentation of $M$. oleifera powder leaves is possible to increase the protein product due to increase of biomass; increasing the reducing sugar content due to the hydrolysis of complex sugars and phenolic compounds. Indeed phenolic compounds are abundant in the young stages of development of plants [16]; they reduce the onset of maturation and then become stable [17].

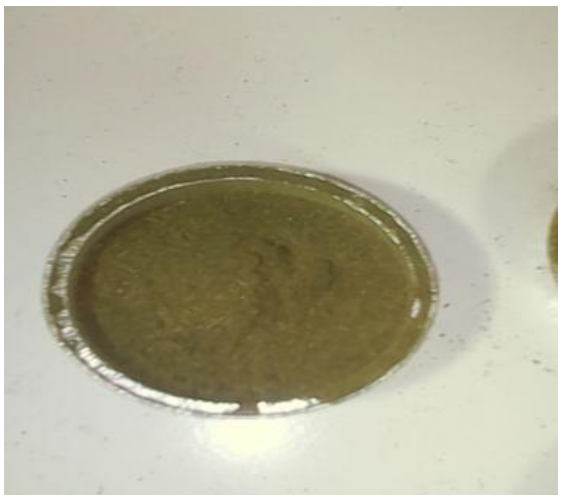

Fig. 2a. M. oleifera powder leaves unfermented

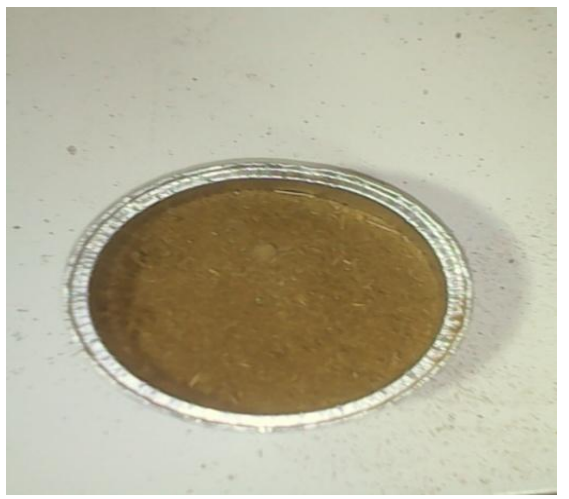

Fig. 2b. M. oleifera powder leaves fermented

\section{CONCLUSION}

The fermentation powder leaves of $M$. oleifera gives a food of high protein value which will be able to contribute in the fight against malnutrition. The freeze-dried fermented powder can be used to enrich pastes of tamarind or pastes of banana, as we tested it, or of other food support [3].

\section{COMPETING INTERESTS}

Authors have declared that no competing interests exist.

\section{REFERENCES}

1. Fao, Banque de données Faostat; 20132014.

2. Saint Sauveur A, Broin M. Moringa et autres végétaux à fort potentiel nutritionnel: L'utilisation des feuilles de Moringa oleifera contre les carences alimentaires: Un potentiel encore peu valorisé. Accra, Ghana, 16-18 Novembre ; 2006. French

3. Harimalala Andriambelo N, Rasoarahona F Razanamparany LJ. Nutritional quality of fruit pastes enriched with Moringa oleifera leaves. International Journal of Applied Science and Technology. 2014; 4:(5).

4. Busina M, Patrick J, Masika AH, Voster M. Nutritional characterization of Moringa (Moringa oleifera Lam.) leaves. African Journal of Biotechnology. 2011;10:1292512933.

5. Sengev Al, Abu OJ, Gernah DI. Effect of Moringa oleifera leaf powder supplementation on some quality characteristics of wheat bread. Journal Food and Nutrition Sciences. 2013;4:270275.

6. Vongsak $B$, Sithisarn $P$, Mangmool $S$, Thongpraditchote S, Wongkrajang $\mathrm{Y}$, Gritsanapan W. Maximizing total phenolic, total flavonoids contents and antioxidant activity of Moringa oleifera leaf extract by the appropriate extraction method in Industrial Crops and Products. 2013;44: 566-571.

7. Owusu D, Oduro I, Ellis WO. Development of crackers from cassava and sweet potato flours using Moringa oleifera and Ipomoea batatas leaves as fortificant. American Journal of Food and Nutrition. 2011;1(3): 114-122.

8. Dachana KB, Rajiv J, Indrani D, Prakash J. Effect of dried Moringa (Moringa oleifera Lam) leaves on rheological, microstructural, nutritional, textural and organoleptic characteristics of cookies. Journal of Food Quality. 2010;33:660-677.

9. Tete-Benissan A, Quashie ML, LawsonEvil K, Kokou K, Gbeassor M. Récupération nutritionnelle chez les sujets malnutris $\mathrm{VIH}$ positifs et $\mathrm{VIH}$ négatifs après 
utilisation de feuilles de Moringa oleifera Lam. Journal of Animal and Plant Sciences. 2012;15:2184-2199.

10. Noumo Ngangmou T, Tatsadjieu Ngoune L, Montet DF, Mbofung CM. Effect of pure culture fermentation on biochemical composition of Moringa oleifera Lam leaves powders. Food and Nutrition Sciences. 2013;4:851-859.

11. Bousmaha L, Ouhssine M, Yachioui El. Fermentation du citron par inoculation microbienne. Journal Afrique Science. 2006;02(1):83-93.

12. Messens W, De Vuyst L. Inhibitory substances produced by bacilli isolated from sourdoughs- review. International. Journal Food Microbiology. 2002;72:31-43.

13. Louembe D, Keleke S, Kobawila SC, Nzouzi JP. Bactéries lactiques de la pâte fermentée de maïs au Congo. Journal Tropicultura. 2003;21(1):3-9.

14. Xiong $\mathrm{T}$, Peng $\mathrm{F}$, Liu $\mathrm{Y}$, Deng $\mathrm{Y}$, Wang $\mathrm{X}$, Xie M. Fermentation of Chinese sauerkraut in pure culture and binary co-culture with Leuconostoc mesenteroides and Lactobacillus plantarum. Journal Food Science and Technology. 2014;59:713-717.

15. Bradet C, Guiraud J. Etude des mécanismes physico-chimiques et biologiques responsables du pouvoir de panification de l'amidon fermenté de manioc. Thèse de Doctorat, Université de Montpellier; 1994. French

16. Sposina Sobral Teixeira R, Sant'ana Da Silva A, Santana Ferreira-Leitão V, Pinto Da Silva Bon E. Amino acids interference on the quantification of reducing sugars by the 3,5-dinitrosalicylic acid assay mislead carbohydrase activity measurements. Carbohydrate Research. 2012;363:33-37.

17. Colin-Henrion M. De la pomme à la pomme transformée: Impact de procédé sur deux composés d'intérêt nutritionnel. Caractérisation physique et sensorielle des produits transformés. Thèse de Doctorat. Université d'Angers; 2008. French

(c) 2017 Nirina et al.; This is an Open Access article distributed under the terms of the Creative Commons Attribution License (http://creativecommons.org/licenses/by/4.0), which permits unrestricted use, distribution, and reproduction in any medium, provided the original work is properly cited. 